\title{
Calixpyrrole Derivatives: “Multi Hydrogen Bond” Catalysts for $\gamma$-Butenolide Synthesis
}

\section{Grazia Cafeo $^{2}$, Margherita De Rosa ${ }^{1}$, Franz H. Kohnke ${ }^{2, *}$, Annunziata Soriente ${ }^{1, *}$, Carmen} Talotta $^{1}$ and Luca Valenti ${ }^{2}$

1 Department of Chemistry, University of Salerno, via Ponte don Melillo, 84084 Fisciano (SA), Italy; E-mail: maderosa@unisa.it (M-D.R.)

2 Department of Organic and Biological Chemistry, University of Messina, Salita Sperone 31, 98166 Messina, Italy; E-mails: ella@isengard.unime.it (G.C.), luca.val2@libero.it(L.V.)

* Authors to whom correspondence should be addressed; E-mail: titti@unisa.it; Fax: +3989969603 (A.S.); E-mail: franz@unime.it; Fax: +39090393895 (F-H.K.)

Received: 22 May 2009; in revised form: 7 July 2009 / Accepted: 9 July 2009 / Published: 15 July 2009

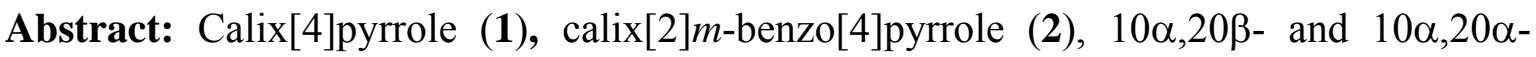
bis(4-nitrophenyl)-calix[4]pyrroles 3 and 4, respectively, were found to exhibit various organocatalytic activities in the diastereoselective vinylogous addition reaction of 2-trimethylsilyloxyfuran (TMSOF, 7) to aldehydes. The $\gamma$-hydroxybutenolide products are obtained in fairly good yields and with moderate diastereoselectivity. The structures of the catalysts, as well as the reaction conditions, strongly influence the efficiency of the reaction.
\end{abstract}

Keywords: calixpyrroles; diastereoselective synthesis; organocatalysis; aldol addition; 2-Trimethyl-silyloxyfuran

\section{Introduction}

Calixpyrroles are macrocyclic compounds capable of binding anions and neutral molecules by means of multiple hydrogen bonds with their pyrrole NH units [1-3]. Calix[4]pyrrole (1) is the simplest member of this class of receptors. As hydrogen bond donors, calixpyrroles have a potential to behave as organocatalysts in a way similar to that reported for taddols [4-5], binols [6-9], urea and 
thiourea derivatives [10-16]. Very recently we reported the first example (and proof) of this property for the hetero-Diels-Alder reaction of Danishefsky's diene with $p$-nitrobenzaldehyde organocatalysed by $10 \alpha, 20 \beta$-bis(4-nitrophenyl)-calix[4]pyrrole (3) [17]. Moreover, we have recently shown that the $10 \alpha, 20 \alpha$-isomer 4 can selectively recognize topologically different dihydroxyaphthalene oxoanions and can be used to achieve regioselective alkylations and acylation reactions [18].

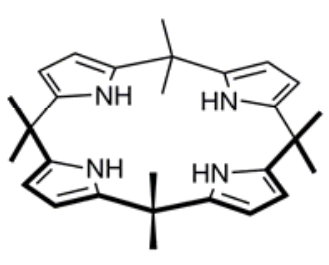

1

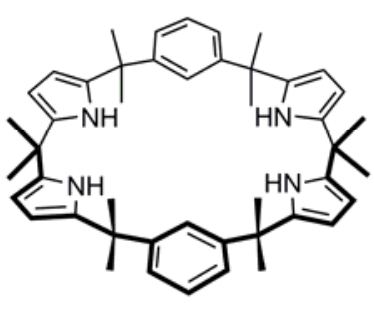

2

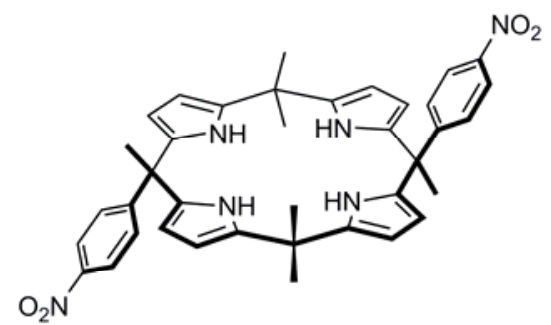

3

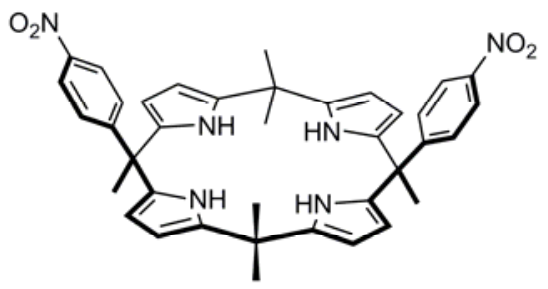

4

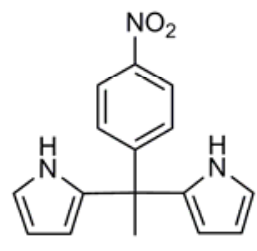

5

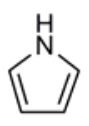

6

During our studies on the development of efficient organocatalysts for the addition of 2-trimethylsilyloxyfuran (TMSOF, 7) to aldehydes 8 we found that $N, N^{\prime}$-bis[3-(trifluoromethyl)phenyl] urea activates carbonyl compounds through hydrogen-bonding interactions, and accelerates these vinylogous aldol reactions [19].

The products of this versatile carbon-carbon bond forming reaction are butenolide-like compounds which represent a substructure of a more complex assembly found in numerous biologically important natural and synthetic products [20-23]. The diastereoselective addition of variously substituted furanbased silyloxydiene synthons to a variety of achiral aldehydes and acetals using Lewis acids as catalysts has been reported in a number of papers [24-30]. MacMillan described the first enantioselective organocatalytic 1,4-addition of TMSOF to unsaturated aldehydes with high enantioselectivities [31]. However, our recent paper [19] describes the only example reported to date of an "organocatalyzed" aldol addition reaction of TMSOF to aldehydes.

Scheme 1. Diastereoselective addition reaction of TMSOF to aldehydes.

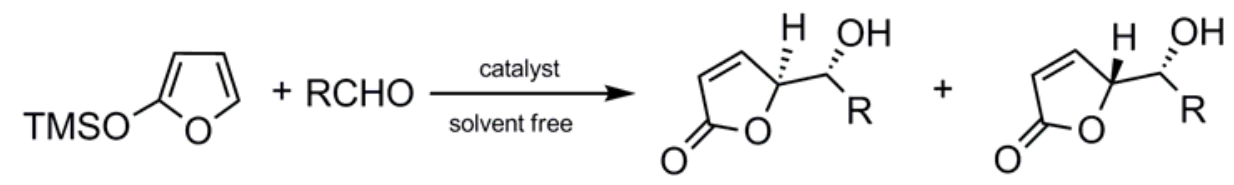

$$
7 \quad \text { 8a-i erythro-9a-i threo-9a-i }
$$
a: $\mathrm{R}=\mathrm{Ph}$;
b: $\mathrm{R}=p-\mathrm{CH}_{3} \mathrm{C}_{6} \mathrm{H}_{4}$;
c: $\mathrm{R}=p-\mathrm{CF}_{3} \mathrm{C}_{6} \mathrm{H}_{4}$;
d: $\mathrm{R}=p-\mathrm{OCH}_{3} \mathrm{C}_{6} \mathrm{H}_{4}$;
e: $\mathrm{R}=o-\mathrm{OCH}_{3} \mathrm{C}_{6} \mathrm{H}_{4}$;
f: $\mathrm{R}=2$-furyl;
g: $\mathrm{R}=\mathrm{C}_{7} \mathrm{H}_{15}$;
h: $\mathrm{R}=\mathrm{C}_{10} \mathrm{H}_{21}$;
$\mathbf{i}=\mathrm{CH}_{3} \mathrm{COCOOEt}$ 
As part of our continuing research in this area, here we report a synthetic approach to compounds of type 9, in which several calixpyrrole derivatives were used as organocatalysts for the first time.

\section{Results and Discussion}

We selected the reaction of TMSOF (7) with benzaldehyde (8a) as an initial test of the catalytic properties of the calixpyrroles 1-4. Compared to calix[4]pyrrole (1), receptors 2, 3, and 4 exhibit various selectivity towards the binding of anions, and in many instances they are stronger complexing agents [32-33]. To the extent that this feature arises from an enhanced ability to act as hydrogen bond donors, macrocycles 2-4 could be expected to be superior to $\mathbf{1}$ as organocatalysts. Macrocycles $\mathbf{3}$ and $\mathbf{4}$ also provide a means to explore the role of the stereochemically different substitution at two mesopositions. Dipyrromethane $\mathbf{5}$ and pyrrole $\mathbf{6}$ were also tested as catalysts because they represent structural units contained in 1-4.

In an initial screening, the reactions were carried out at room temperature $\left(25^{\circ} \mathrm{C}\right)$ for $24 \mathrm{~h}$, with $20 \% \mathrm{~mol}$ of the catalyst, based on TMSOF $(0.5 \mathrm{mmol})$, without added solvent, the liquid benzaldehyde ( $2.5 \mathrm{mmol}$ ) being both the reactant and the solvent [19]. The silylated aldols were directly deprotected using Carreira's procedure [34] to give the aldols erythro-9a and threo-9a. All reactions (including those described later in this paper) were repeated at least three times, and the yields were found to be reproducible within 5\%. In all cases, the catalysts were found to be unaffected at the end of the reaction and their recovery by flash chromatography was a viable option which was undertaken in some cases. The experimental results are summarized in Table 1.

Table 1. Results for the screening of catalysts 1-6 in the aldol addition of $\mathbf{7}$ to $8 \mathbf{a}^{[\mathrm{a}]}$.

\begin{tabular}{cccc}
\hline Entry & Catalyst & Yield (\%) $^{[\mathbf{b}]}$ & erythro/threo $^{[\mathbf{c}]}$ \\
\hline 1 & - & 0 & - \\
2 & $\mathbf{1}$ & 45 & $70 / 30$ \\
3 & $\mathbf{2}$ & 63 & $80 / 20$ \\
4 & $\mathbf{3}$ & 12 & $70 / 30$ \\
5 & $\mathbf{4}$ & 30 & $70 / 30$ \\
6 & $\mathbf{5}$ & 16 & $60 / 40$ \\
7 & $\mathbf{6}$ & 25 & $70 / 30$ \\
8 & $\mathbf{6}$ & 0 & - \\
\hline
\end{tabular}

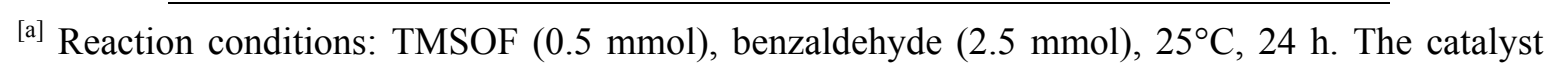
was $20 \mathrm{~mol} \%$ (based on TMSOF) in all cases with the exception of entry 8 , where $80 \mathrm{~mol} \%$ catalyst was used; [b] Combined isolated yield of erythro-9a and threo-9a; [c] The diastereoisomeric ratio (erythro/threo) was determined by ${ }^{1} \mathrm{H}-\mathrm{NMR}$ analysis of the crude product according to literature data [35].

In the absence of catalysts (Table 1, entry 1), no reaction is observed. Calix[4]pyrrole (1) (Table 1, entry 2) acts as a Lewis acid and enhances the reactivity of 8a towards TMSOF 7, affording the adducts 9a in 45\% yield with a good diastereomeric ratio. Macrocycles 3 and $\mathbf{4}$ (Table 1, entries 4-5) were found to be less active than the parent compound $\mathbf{1}$, although they are stronger hydrogen-bond donors than 1 towards anions (e.g. fluoride). We believe this reduced activity to be due to the steric 
crowding of the macroring by the p-nitrophenyl units. Macrocycle 2 (Table 1, entry 3) was the most effective catalyst, probably because it is also the best anion ligand and it also lacks steric barriers at the meso-positions. When used in a $20 \%$ molar ratio, pyrrole 6 (Table 1, entry 7 ) was almost as active as macrocycle 4, but surprisingly it was totally inactive (no reaction was observed) at an $80 \%$ molar ratio (Table 1, entry 8, to account for the presence of four pyrrole units in the macrocycles under scrutiny). A pattern emerges, whereby the most active catalysts also exhibit the highest diastereomeric ratios.

Table 2. Effects of reaction conditions on the reaction of $\mathbf{7}$ with $\mathbf{8 a}$ catalyzed by $\mathbf{1}$ and $\mathbf{2 .}$

\begin{tabular}{ccccc}
\hline Entry & Catalyst (mol\%) & ${ }^{\circ} \mathbf{C} / \mathbf{h}$ & Yield (\%) $^{[\mathbf{b}]}$ & erythro/threo $^{[\mathbf{c}]}$ \\
\hline $1^{[\mathrm{a}]}$ & $\mathbf{1}(20)$ & $25^{\circ} / 48$ & 82 & $70 / 30$ \\
$2^{[\mathrm{a}]}$ & $\mathbf{1}(20)$ & $25^{\circ} / 72$ & 18 & $70 / 30$ \\
$3^{[\mathrm{a}]}$ & $\mathbf{1}(20)$ & $40^{\circ} / 24$ & 7 & $70 / 30$ \\
$4^{[\mathrm{a}]}$ & $\mathbf{2}(20)$ & $25^{\circ} / 48$ & 74 & $70 / 30$ \\
$5^{[\mathrm{a}]}$ & $\mathbf{2}(20)$ & $40^{\circ} / 48$ & 34 & $78 / 22$ \\
\hline
\end{tabular}

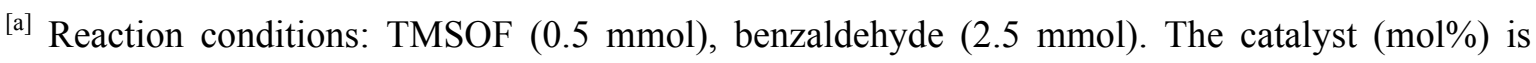
based on TMSOF; ${ }^{[\mathrm{b}]}$ Combined isolated yield of erythro-9a and threo-9a; ${ }^{[\mathrm{c}]}$ The diastereoisomeric ratio (erythro/threo) was determined by ${ }^{1} \mathrm{H}-\mathrm{NMR}$ analysis on the crude product according to literature data [35].

We then investigated the effects of changes in the reaction conditions in order to improve the activity of the best catalysts 1 and 2 (see Table 2). With catalyst 1, compared to the initially tested conditions (Table 1, entry 2), extending the reaction time to $48 \mathrm{~h}$ increased the yield to $82 \%$ (Table 2 , entry 1), but longer periods (Table 2, entry 2) gave lower yields, probably because of a retro-aldol reaction. At a higher temperature, (Table 2, entry 3) the yields decreased, probably because of a reduced binding between the catalyst and the aldehyde.

With catalyst 2, extending the reaction time from 24 (Table 1, entry 3 ) to $48 \mathrm{~h}$ (Table 2, entry 4) increased the yield of adducts 9a from 63 to 74\%, but with no improvement in the diastereomeric ratio. At a higher temperature the yields of 9a were reduced (Table 2, entry 5).

Encouraged by the results obtained for the reaction with benzaldehyde, we tested the scope and limitations of this reaction with different aldehydes in the best conditions (see Table 2, entries 1 and 4) found for catalysts 1 and 2. The results are reported in Table 3. Entry 8 shows that these catalysts are also effective when the carbonyl unit is that of an activated ester. For the different aldehydes the yields of the reactions are generally consistent with the reactivities observed with other hydrogen-bonding organocatalysts. Thus, for example, $\mathbf{8} \mathbf{c}$ is more reactive than $\mathbf{8 b}$, and aliphatic aldehydes are generally less reactive than the aromatic ones.

However, there are significant differences in the yields for several aldehydes, depending on the catalyst used. The most remarkable of these are entries 3, 4, 5, and 7. Moreover, catalyst 2 appears more selective than 1 towards some different aldehydes (e.g. see entries 2 and 4 in Table 3 ).

There are a number of organocatalysts for the reactions described here that are more readily accessible than the calixpyrroles used in this study [19]. However, the observed selectivity of the calixpyrroles towards different substrates is a feature of particular interest in view of future 
applications that involve the combination of molecular recognition with organocatalytic properties. This concept has been highlighted as an appealing goal in supramolecular catalytic systems [36].

Table 3. Aldol reaction of TMSOF (7) with carbonyl compounds $\mathbf{8 b - i}$ catalyzed by $\mathbf{1}$ or $\mathbf{2}^{[\mathrm{a}]}$.

\begin{tabular}{|c|c|c|c|c|c|}
\hline Entry & Substrate & $\begin{array}{c}\text { Yield (\%) } \\
\text { with } 1\end{array}$ & $\begin{array}{c}\text { Yield (\%) } \\
\text { with } 2 \\
\end{array}$ & $\begin{array}{c}\text { erythro/threo } \\
\text { with } 1^{[\mathrm{c}]} \\
\end{array}$ & $\begin{array}{c}\text { erythro/threo } \\
\text { with } 2^{[\mathrm{c}]} \\
\end{array}$ \\
\hline 1 & $p-\mathrm{CH}_{3}-\mathrm{C}_{6} \mathrm{H}_{4} \mathrm{CHO}(\mathbf{8 b})$ & 40 & 40 & $80 / 20$ & $80 / 20$ \\
\hline 2 & $p-\mathrm{CF}_{3}-\mathrm{C}_{6} \mathrm{H}_{4} \mathrm{CHO}(\mathbf{8 c})$ & 58 & 50 & $70 / 30$ & $70 / 30$ \\
\hline 3 & $p-\mathrm{OCH}_{3}-\mathrm{C}_{6} \mathrm{H}_{4} \mathrm{CHO}(\mathbf{8 d})$ & 25 & 4 & $80 / 20$ & - \\
\hline 4 & $\mathrm{o}-\mathrm{OCH}_{3}-\mathrm{C}_{6} \mathrm{H}_{4} \mathrm{CHO}(\mathbf{8 e})$ & 15 & 0 & $70 / 30$ & - \\
\hline 5 & 《त्र ${ }_{\mathrm{CHO}}$ (8f) & 70 & 56 & $70 / 30$ & $70 / 30$ \\
\hline 6 & $\mathrm{C}_{7} \mathrm{H}_{15} \mathrm{CHO}(\mathbf{8 g})$ & 30 & 40 & $70 / 30$ & $70 / 30$ \\
\hline 7 & $\mathrm{C}_{10} \mathrm{H}_{21} \mathrm{CHO}(\mathbf{8 h})$ & 16 & 30 & $70 / 30$ & $70 / 30$ \\
\hline 8 & $\mathrm{CH}_{3} \mathrm{COCOOEt}$ (8i) & 63 & 63 & $70 / 30$ & $70 / 30$ \\
\hline
\end{tabular}

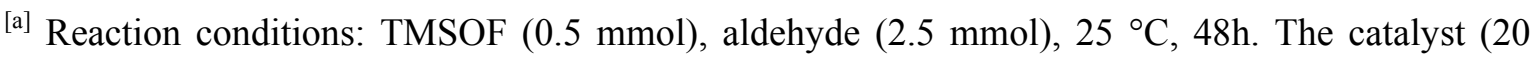
mol\%) is based on TMSOF; ${ }^{[b]}$ Combined isolated yield of erythro-9a and threo-9a; ${ }^{[c]}$ The diastereoisomeric ratio (erythro/threo) was determined by ${ }^{1} \mathrm{H}-\mathrm{NMR}$ analysis on the crude product according to literature data [35].

\section{Experimental}

\section{General}

All chemicals were standard reagent grade and were used without further purification. All airsensitive and/or moisture-sensitive reactions were conducted under an inert atmosphere. Thin-layer chromatography was performed on Merck Kiesegel $60(0.25 \mathrm{~mm})$ eluting with the solvents indicated, visualized by a $254 \mathrm{~nm}$ UV lamp or aqueous ceric sulfate solution followed by heating. Column chromatography was carried out using silica gel 60 (70-230 mesh, Merck). NMR spectra were recorded on a Bruker DRX 400 (400.13 $\mathrm{MHz}$ for ${ }^{1} \mathrm{H}$ and 100.03 for $\left.{ }^{13} \mathrm{C}\right)$.

\section{General Procedure for the Organocatalytic Addition of TMSOF to Aldehydes}

A mixture of catalyst 1 or $2(0.1 \mathrm{mmol})$ and the appropriate aldehyde $\mathbf{8 a}-\mathbf{i}(2.5 \mathrm{mmol})$ was stirred at room temperature for 15 minutes. Then, TMSOF $(7,84 \mu \mathrm{L}, 0.5 \mathrm{mmol})$ was added dropwise and the resulting solution was stirred at room temperature for the time reported in Tables 1-3. The progress of the reaction was monitored by TLC. Upon completion, the mixture was cooled at $-30^{\circ} \mathrm{C}$ and THF $(0.5$ $\mathrm{mL})$ and TFA $(0.2 \mathrm{~mL})$ were added. The solution was then warmed to r.t. and stirred for $1 \mathrm{~h}$ after which the desilylation was complete. The reaction mixture was diluted with ethyl acetate and a saturated aqueous solution of $\mathrm{NaHCO}_{3}(2 \mathrm{~mL})$ was added dropwise. The mixture was stirred until the evolution of gas ceased (30 $\mathrm{min}$ ), the organic layer was then separated, washed with brine, dried over $\mathrm{MgSO}_{4}$, and concentrated in vacuo. The crude mixture was purified by silica gel column chromatography (eluent: hexane/ethyl acetate) to afford a mixture of the corresponding diastereomeric butenolides 9a-i. The products are all known compounds identified by their spectroscopic data and 
comparison with literature values $[19,37,38]$. The diastereomeric ratio was determined by ${ }^{1} \mathrm{H}-\mathrm{NMR}$ analysis.

\section{Conclusions}

The results described here prove that the exploration of the organocatalytic properties of calixpyrrole derivatives, which we started just over one year ago, is still rich in novel possibilities. Thus, the calixpyrroles 1-4 displayed varied organocatalytic activities in the diastereoselective vinylogous addition reaction of 2-trimethylsilyloxyfuran to aldehydes, affording $\gamma$-hydroxybutenolide products. The fairly good yields and moderate diastereoselectivities obtained were comparable to those previously observed with other organocatalysts [19]. We are actively involved in testing the activity of various calixpyrroles as organocatalysts in other different reactions.

\section{Acknowledgements}

This work was supported by the University of Salerno and by the University of Messina.

\section{References and Notes}

1. Lee, C.H.; Miyaji, H.; Yoon, D.W.; Sessler, J.L. Strapped and other topographically nonplanar calixpyrrole analogues. Improved anion receptors. Chem. Commun. 2008, 24-34.

2. Gale, P.A.; Anzenbacher, P., Jr.; Sessler, J.L. Calixpyrroles II. Coord. Chem. Rev. 2001, 222, 57-102.

3. Gale, P.A.; Sessler, J.L.; Kral, V. Calixpyrroles. Chem. Commun. 1998, 1-8 and references therein.

4. Akiyama, T.; Itoh, J.; Fuchibe, K. Recent Progress in Chiral Brønsted Acid Catalysis. Adv. Synth. Catal. 2006, 348, 999-1010 and references threin.

5. Gondi, V.B.; Gravel, M.; Rawal, V.H. Hydrogen bond catalyzed enantioselective vinylogous Mukaiyama aldol reaction. Org. Lett. 2005, 7, 5657-5660.

6. Hou, Z.R.; Wang, J.; Liu, X.H.; Feng, X.M. Highly enantioselective Strecker reaction of ketoimines catalyzed by an organocatalyst from (S)-BINOL and L-prolinamide. Chem. Eur. J. 2008, 14 , 4484-4486.

7. Wanner, M.J.; Hauwert, P.; Schoemaker, H.E.; de Gelder, R.; van Maarseveen, J.H.; Hiemstra, H. Synthesis of enantiopure (S)-indolyglycine by organocatalyzed Friedel-Crafts alkylation of indole. Eur. J. Org. Chem. 2008, 1, 180-185.

8. Page, P.C.B.; Farah, M.M.; Buckley, B.R.; Blacker, A.J. New chiral binaphthalene-derived iminium salt organocatalysts for asymmetric epoxidation of alkenes. J. Org. Chem. 2007, 72, 4424-4430.

9. Rueping, M.; Ieawsuwan, W.; Antonchick, A.P.; Nachtsheim, B.J. Chiral Bronsted acids in the catalytic asymmetric Nazarov cyclization- The first enantioselective organocatalytic electrocyclic reaction. Angew. Chem., Int. Ed. 2007, 46, 2097-2100.

10. Connon, S.J. Asymmetric catalysis with bifunctional cinchona alkaloid-based urea and thiourea organocatalysts. Chem. Comm. 2008, 2499-2510. 
11. Weil, T.; Kotke, M.; Kleiner, C.M.; Schreiner, P.R. Cooperative Bronsted acid-type organocatalysis: alcoholysis of styrene oxides. Org. Lett. 2008, 10, 1513-1516.

12. Peschiulli, A.; Gun'ko, Y.; Connon, S.J. Highly enantioselective desymmetrization of meso anhydrides by a bifunctional thiourea-based organocatalysts at low catalyst loadings and room temperature. J. Org. Chem. 2008, 73, 2454-2457.

13. Fleming, E.M.; Quigley, C.; Rozas, I.; Connon, S.J. Computational study-led organocatalyst design: a novel, highly active urea-based catalyst for addition reactions to epoxides. J. Org. Chem. 2008, 73, 948-956.

14. Shi, Y.L.; Shi, M. Chiral thiourea-phosphine organocatalysts in the asymmetric Aza-MoritaBaylis-Hillman reaction. Adv. Synth. Catal. 2007, 349, 2129-2135.

15. Connon, S.J. Organocatalysis mediated by (thio)urea derivatives. Chem. Eur. J. 2006, 12, 5418-5427.

16. Seayad, J.; List, B., Asymmetric organocatalysis. Org. Biomol. Chem. 2005, 3, 719-724.

17. Cafeo, G.; De Rosa, M.; Kohnke, F.H.; Neri, P.; Soriente, A.; Valenti, L. Efficient organocatalysis with a calix[4]pyrrole derivative Tetrahedron Lett. 2008, 49, 153-155.

18. Cafeo, G.; Kohnke, F.H.; Valenti, L. Regioselective O-alkylations and acylations of polyphenolic substrates using a calix[4]pyrrole derivative. Tetrahedron Lett. 2009, 50, 4138-4140.

19. De Rosa, M.; Citro, L.; Soriente, A. The first organocatalytic addition of 2-trimethylsilyloxyfuran to carbonyl compounds: hydrogen-bond catalysis in $\gamma$-butenolides synthesis. Tetrahedron Lett. 2006, 47, 8507-8510.

20. Smith, C.J.; Abbanat, D.; Bernan, V.S.; Maiese, W.M.; Greenstein, M.; Jompa, J.; Tahir, A.; Ireland, C.M. Novel Polyketide Metabolites from a Species of Marine Fungi. J. Nat. Prod. 2000, 63, 142-145.

21. Schuyler, A.; Caufield, C.E.; Hu, W.; Keeney, D.; Labthavikul, P.; Morris, K.; Naughton, S.M.; Petersen, P.J.; Rasmussen, B.A.; Singh, G.; Yang, Y. Pulvinones as bacterial cell wall biosynthesis inhibitors. Bioorg. Med. Chem. Lett. 2006, 16, 176-180.

22. Li, R.T.; Han, Q.B.; Zheng, Y.T.; Wang, R.R.; Yang, L.M.; Lu, Y.; Sang, S.Q.; Zheng, Q.T.; Zhao, Q.S.; Sun, H.D. Structure and anti-HIV activity of micrandilactones B and C, new nortriterpenoids possessing a unique skeleton from Schisandra micrantha. Chem. Comm. 2005, 2936-2938.

23. Dalpiaz, A.; Pavan, B.; Scaglianti, M.; Vitali, F.; Bortolotti, F.; Biondi, C.; Scatturin, A.; Manfredini, S. Vitamin C and 6-amino-vitamin C conjugates of diclofenac: synthesis and evaluation. Int. J. Pharm. 2005, 291, 171-181.

24. Pelter, A.; Al-Bayati, R.I.H.; Ayoub, M.T.; Lewis, W.; Pardasani, P.; Hänsel, R., Synthetic Routes to the Piperolides, Fadyenolides, Epoxypiperolides, and Related Compounds. J. Chem. Soc. Perkin Trans. 1 1987, 717-742.

25. Boukouvalas, J.; Maltais, F. An efficient total synthesis of antibiotic patulin. Tetrahedron Lett. 1995, 36, 7175-7176.

26. Boukouvalas, J.; Maltais, F. An Efficient Total Synthesis of Neopatulin. Tetrahedron Lett. 1994, $35,5769-5770$. 
27. Boukouvalas, J.; Maltais, F.; Lachance, N. Furanolate-Based Strategy for Sequential 2,3,4Trisubstitution of Butenolide: Total Synthesis of Nostoclides I and II. Tetrahedron Lett. 1994, 35, 7897-7900.

28. Boukouvalas, J.; Lachance, N.; Ouellet, M.; Trudeau, M., Facile Access to 4-aryl-2(5H)furanones by Suzuki cross coupling: efficient synthesis of rubrolides $\mathrm{C}$ and E. Tetrahedron Lett. 1998, 39, 7665-7668.

29. By Xu, D.; Sharpless, K.B. Synthesis and stereochemical assignments for goniobutenolides A and B. Tetrahedron Lett. 1994, 35, 4685-4688.

30. Von der Ohe, F.; Brückner, R. Z- or E-configurated $\gamma$-alkylidenebutenolides from a 2(trimethylsiloxy)furan and iodomethacrolein stereoselective synthesis of Z- and E-freelingyne. Tetrahedron Lett. 1998, 39, 1909-1910.

31. Brown, S.P.; Goodwin, N.C.; MacMillan, D.W.C. The first enantioselective organocatalytic Mukaiyama-Michael reaction: a direct method for the synthesis of enantioenriched $\gamma$-butenolide architecture. J. Am. Chem. Soc. 2003, 125, 1192-1194.

32. Cafeo, G.; Kohnke, F.H.; White, A.J.P.; Garozzo, D.; Messina, A. Syntheses, structure, and anion-binding properties of two novel calix[2]benzo[4]pyrroles. Chem. Eur. J 2007, 13, 649-656.

33. Bruno, G.; Cafeo, G.; Kohnke, F.H.; Nicolò, F. Tuning the anion binding properties of calixpyrroles by means of p-nitrophenyl substituents at their meso-positions. Tetrahedron 2007, 63, 10003-10010.

34. Kruger, J.; Carreira, E.M. Apparent catalytic generation of chiral metal enolates: Enantioselective dienolate additions to aldehydes mediated by Tol-BINAP-Cu(II)fluoride complexes. J. Am. Chem. Soc. 1998, 120, 837-838.

35. Szlosek, M.; Figadére, B. Highly enantioselective aldol reaction with 2-trimethylsiloxyfuran: the first catalytic asymmetric autoinductive aldol reaction. Angew. Chem. Int. Ed. 2000, 39, 1799-1801.

36. Reinhoudt, D.N.; Crego-Calama, M. Synthesis Beyond the Molecule. Science 2002, 295, 2403-2407.

37. Acocella, M.R.; De Rosa, M.; Massa, A.; Palombi, L.; Villano, R.; Scettri, A. Silicon tetrachloride in organic synthesis: new applications for the vinylogous aldol reaction. Tetrahedron 2005, 61, 4091-4097.

38. Brown, D.W.; Campbell, M.M.; Taylor, A.P.; Zhang, X.A. Regio- and diastereoselectivity in aldol reactions of cyclopent-2-enone, $2-(5 \mathrm{H})$ furanone and their derived trimethylsilyloxydienes. Tetrahedron Lett. 1987, 28, 985-988.

Sample Availability: Samples of the compounds of interest are available from the authors.

(C) 2009 by the authors; licensee Molecular Diversity Preservation International, Basel, Switzerland. This article is an open-access article distributed under the terms and conditions of the Creative Commons Attribution license (http://creativecommons.org/licenses/by/3.0/). 